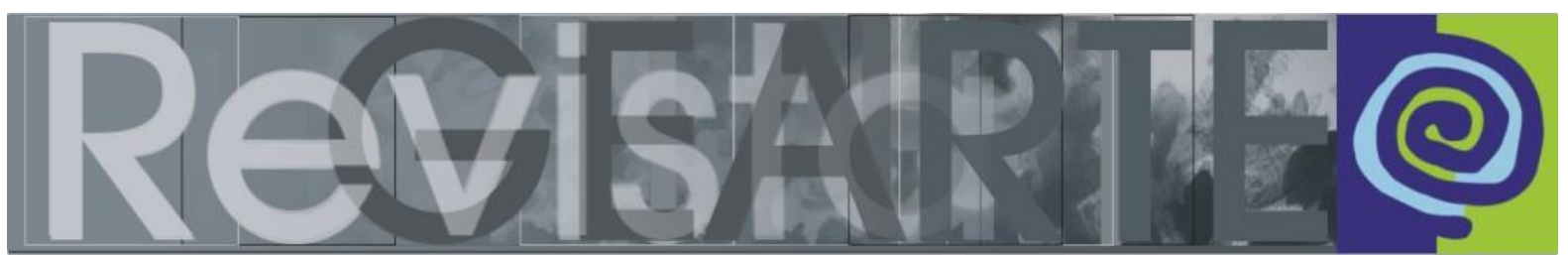

ISSN 2357-9854 | e-ISSN 2596-3198 (online)

\title{
Criação e avaliação em arte na formação de professoras
}

\author{
Marcia Strazzacappa \\ (Universidade Estadual de Campinas - UNICAMP, Campinas/SP, Brasil)
}

\begin{abstract}
RESUMO - Criação e avaliação em arte na formação de professoras - Avaliar não é tarefa fácil. Trata-se de uma ação pouco prazerosa, tanto para o/a avaliador/a quanto para o/a avaliado/a. Quando se trata de avaliar em aula de arte, parece que a ação se torna ainda mais complexa. Afinal, avaliar o quê? O processo? O produto? E quando o produto não é palpável como um desenho ou uma escultura? Como avaliar levando em consideração a dimensão subjetiva da arte? Se o conhecimento em arte é construído na prática, na ação e na criação, defendo a posição de que o mesmo deveria ocorrer na avaliação, que deveria ser vista como parte do processo de aprendizagem. Para justificar essa afirmativa, o artigo apresenta algumas reflexões sobre avaliações ocorridas numa disciplina obrigatória do curso de Pedagogia.
\end{abstract}

\section{PALAVRAS-CHAVE}

Avaliação em arte. Processos criativos. Formação de professores.

ABSTRACT - Creation and evaluation of arts in teacher education - Evaluating is not an easy task. This is an unpleasant action, both for the evaluator and for the evaluated person. When it comes to evaluating in art class, it seems that it becomes even more complex. After all, evaluate what? The process? The product? And when the product is not tangible like a drawing or a sculpture? How to evaluate taking into account the subjective dimension of art? If knowledge in art is built in practice, in action and in creation, the same should happen in the evaluation process. This article argues that art assessment should be constant and understood as part of the learning process. To justify this assertion, the article presents some reflections on assessments that took place in a compulsory subject in the Pedagogy Course.

KEYWORDS

Evaluation of Arts. Creative process. Teacher education.

RESUMEN - Creación y evaluación de las artes en la formación del profesorado - Evaluar no es tarea fácil. Esta es una acción desagradable, tanto para el evaluador como para la persona evaluada. A la hora de evaluar en clase de arte, parece que la acción se vuelve aún más compleja. ¿Después de todo, evaluar qué? ¿El proceso? ¿El producto? ¿Y cuando el producto no es tangible como un dibujo o una escultura? ¿Cómo evaluar teniendo en cuenta la dimensión subjetiva del arte? Este artículo sostiene que la evaluación del arte debe ser constante y entenderse como parte del proceso de aprendizaje. Para justificar esta afirmación el artículo presenta algunas reflexiones sobre las evaluaciones que se realizaron en una asignatura del curso de pedagogía.

\section{PALABRAS CLAVE}

Evaluación de las artes. Proceso creativo. Formación del profesorado de escuela. 


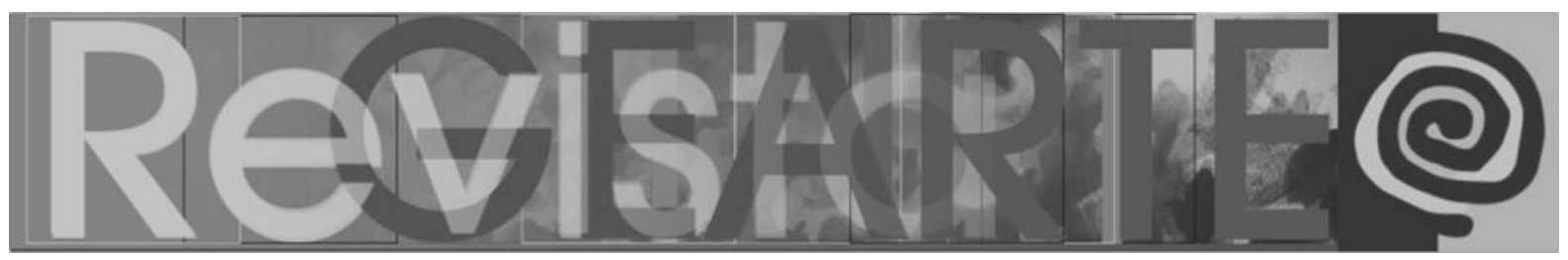

\section{Introdução}

"Educação, corpo e arte" é como se intitula a disciplina na qual são trabalhados os conteúdos de arte, em suas diferentes linguagens, dentro do curso de formação de professoras ${ }^{1}$ da Faculdade de Educação da Unicamp. Formação de professoras no sentido mais amplo, tendo em vista que essa disciplina é obrigatória no curso de Pedagogia e optativa nas demais licenciaturas ${ }^{2}$ da universidade.

Criada em 1998 como disciplina eletiva, passei a compartilhar sua docência em 2000, ano de meu ingresso no quadro efetivo da Faculdade de Educação. Nesses 20 anos de existência, essa disciplina já foi objeto de pesquisa, mote de comunicações orais e tema de mesas em congressos e reuniões científicas nacionais, como Associação Nacional de Pós-graduação e Pesquisa em Educação (ANPED), Associação Brasileira de Artes Cênicas (ABRACE), Congresso Nacional da Federação dos Arte-Educadores do Brasil (CONFAEB), Encontro Nacional de Didática e Prática de Ensino (ENDIPE), Congresso de Leitura (COLE); e internacionais como International Society for Education through Art (InSEA), Centre de Recherche Interuniversitaire sur la Formation et la Profession Enseignant (CRIFPE), Association Francophone Internationale de Recherche Scientifique en Education (AFIRSE), dentre outros espaços e tempos.

Ao buscar para o presente capítulo abarcar algo que ainda não havia refletido nesses anos de oferecimento da disciplina, algo que fosse original e inédito como foco de discussão, retomei e revisitei os textos já publicados ${ }^{3}$. Ao reler o material, listei os assuntos abordados, que vão da apresentação do desenvolvimento da disciplina à discussão sobre as visões de corpo presentes na escola, passando pela problematização do espaço físico. Vários textos se iniciam com uma breve narrativa sobre a criação da disciplina dentro da Faculdade de Educação, destacando que, de eletiva exclusiva do curso de Pedagogia, tornou-se obrigatória no referido curso e eletiva nas demais licenciaturas; ou ainda que a disciplina à época de sua implantação era ministrada por quatro docentes, sendo 


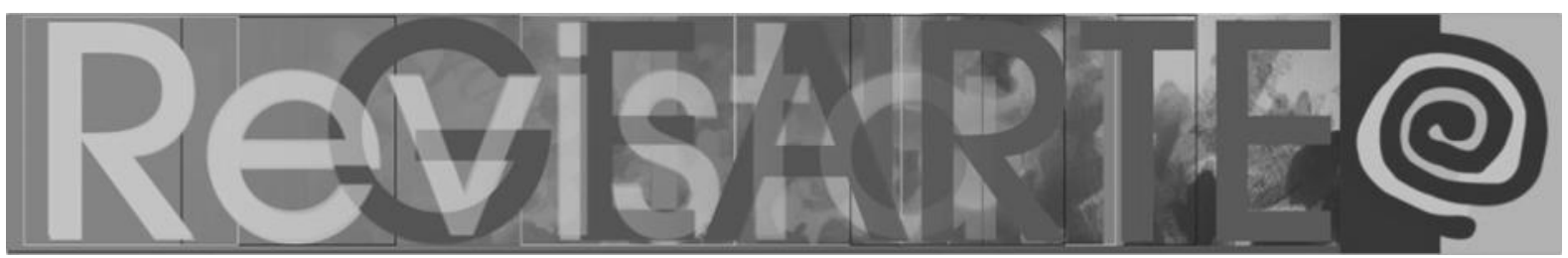

duas de arte (artes visuais e dança/teatro) e duas de educação física e que, atualmente, conta com uma única docente responsável, aprofundando uma linguagem e tendo contato pontual com as demais. Também se destaca a alteração no momento de oferta da disciplina dentro da grade curricular do curso que passou do oitavo para o quarto semestre, ou seja, do último para o segundo ano, permitindo que estudantes pudessem entrar em contato com as questões do corpo e da arte enquanto teorizam sobre o desenvolvimento infantil. Outros artigos dão ênfase ao espaço físico utilizado para as aulas desta disciplina que, diante das propostas abordadas, levou à criação de uma sala específica dentro do prédio de salas de aula da Faculdade de Educação, uma sala vazia, que pudesse acolher, a contento, as diferentes atividades previstas. Segundo Ana Angélica Albano, "a sala ED03 foi nossa contribuição para a diversificação dos ambientes de aprendizagem" (2019, p. 128). Há ainda capítulos nos quais são discutidas as práticas realizadas em sala de aula, sobretudo no tocante à dança e ao teatro, com as diferentes turmas ao longo dos anos, além de narrativas da experiência em ter ofertado outra disciplina semelhante à "Educação, Corpo e Arte", intitulada "PE303 Teoria Pedagógica e Produção em Arte" dentro dos cursos especiais de Pedagogia, quais sejam, o "Programa especial de formação de professores em exercício da rede de ensino de Campinas" (PEFOPEX) e o "Programa especial de formação de professores em exercício da rede pública de ensino" (PROESF), ocorridos entre 2005 e 2008, além de um módulo sobre ensino de arte dentro da disciplina "Gestão, Currículo e Cultura"4, no curso de especialização de gestores do Estado de São Paulo.

Após esse panorama, identifico que até então não havia analisado nem discorrido sobre os processos de avaliação realizados ao longo desses anos ao ministrar essa disciplina e suas correlatas. Assim, opto por tocar nesse assunto delicado e por vezes motivo de amplas discussões, afinal, como avaliar arte? Espero, desta forma, trazer uma nova contribuição para o campo de formação de professores. 


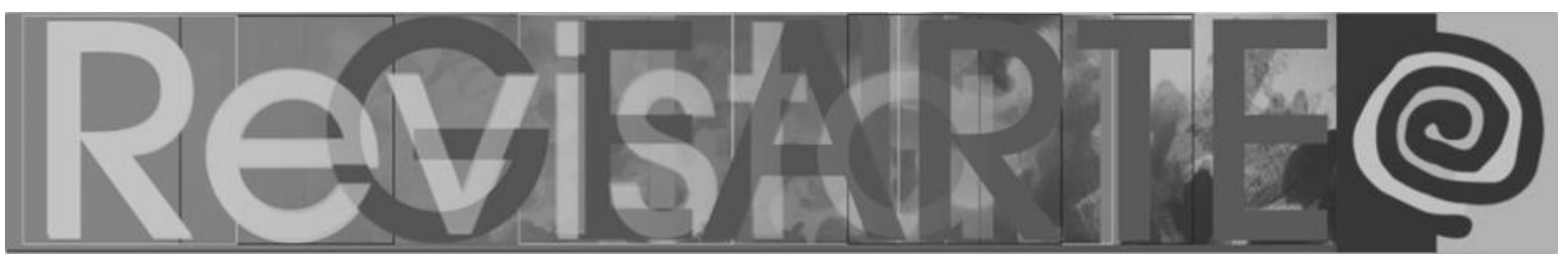

\section{Os processos de avaliação em arte}

Avaliar não é tarefa fácil. Trata-se de uma ação pouco prazerosa, seja para quem faz a avaliação, seja para quem é avaliado. Quando se trata de avaliar a aula de arte, parece que a ação se torna ainda mais complexa. Afinal, avaliar o quê? Como? O processo? O produto? Como avaliar, levando em consideração a dimensão subjetiva da arte? Na literatura encontramos autores que discutem os processos de avaliação em arte, sobretudo no campo das artes visuais (HERNANDEZ, 2000; IAVELBERG, 2015, 2016). Porém, como avaliar quando o resultado/produto não é um desenho, uma escultura, uma instalação, uma fotografia; quando tanto produto quanto processo não é algo palpável, pelo contrário, é algo efêmero, passageiro, em movimento? E que, ainda por cima, ocorre no/com o corpo daquele que produz? Como avaliar sem julgar? As questões são inesgotáveis.

Alguns colegas, diante de tamanha complexidade, optam em simplesmente não avaliar. A justificativa é fundada no fato de preferirem estudantes engajadas nas atividades em sala de aula e nos processos de criação do que preocupadas com nota e frequência. Assim, informam no primeiro dia de aula que ao se matricularem já estão aprovadas e que não será passada lista de presença. Porém, dentro da estrutura escolar ainda vigente, se uma disciplina se propõe a não realizar avaliação e sequer exige presença, pode indicar que se trata de conteúdos menos relevantes, assuntos supérfluos e de menor importância, logo, dispensáveis. É essa mensagem que queremos passar às futuras pedagogas, professoras de crianças de zero a dez anos de idade e aos demais licenciados? A imagem de que o ensino de arte é irrelevante na formação humana?

\section{Presença ativa e frequência}

Tendo como pressuposto de que para se aprender arte é preciso vivenciar processos criativos de/em arte, a disciplina "Educação, Corpo e Arte" passou a ser obrigatória no curso de Pedagogia, como acima apontado. Mesmo assim, um único 


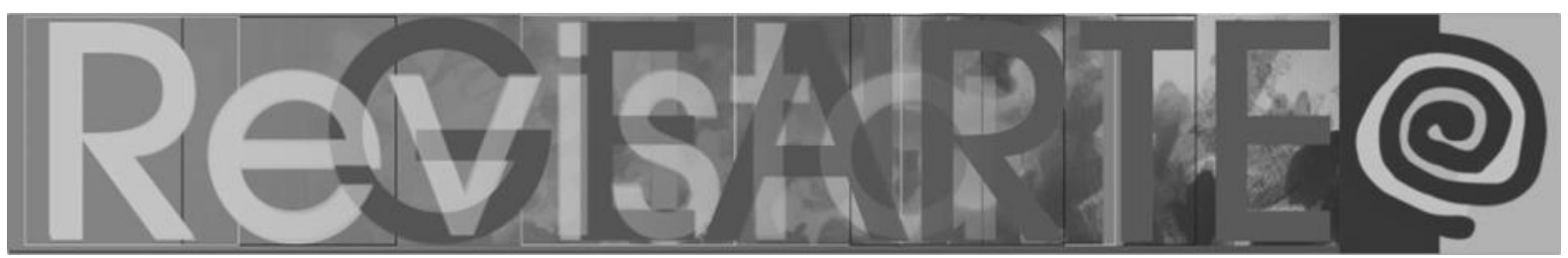

semestre ainda era considerado pouco para se ter um contato efetivo com a arte, lembrando que a construção de conhecimento em arte demanda tempo, mas era essa a realidade. Então, o que fazer para garantir que essas futuras professoras de crianças, de fato, passassem pela experiência na disciplina? Vivenciassem as propostas de arte ao longo do semestre? Como permitir que esse único semestre pudesse fazer a diferença na formação dessas estudantes?

Uma das formas encontradas para, no mínimo, conduzir as estudantes de Pedagogia a cursar obrigatoriamente a disciplina de forma presencial e assim garantir a experiência, foi lançar mão de um recurso administrativo acadêmico. Solicitamos que 0 vetor de carga horária ${ }^{5}$ da disciplina fosse "Atividade de Laboratório", conhecido como código L.

\begin{abstract}
Atividade de Laboratório (código L) - é o campo que expressa o equivalente em horas semanais que envolvem efetivamente alunos e professores, em tempo integral, no desenvolvimento prático dos conteúdos, dentro de um ambiente projetado e adequado para esse fim, onde se incluem os laboratórios científicos, experimentais, corporais, computacionais, palco, campo experimental e outras atividades definidas a critério da CCG (Regimento Geral da Graduação, Capítulo II, Seção VI, artigo 27 , grifo nosso). ${ }^{6}$
\end{abstract}

Outro recurso foi destacar que a avaliação fazia parte integrante do processo de formação do indivíduo e que a presença em sala de aula seria levada em conta na avaliação. Uma presença ativa, viva, participante. Somente a presença física de estudantes permite que as pessoas vivenciem processos de criação coletiva, permite a consciência de sua individualidade, ao ser um corpo único e, ao mesmo tempo, a compreensão de sua pluralidade ao fazer parte de um corpo coletivo.

O Regimento Geral da Universidade Estadual de Campinas prevê a possibilidade de se avaliar disciplinas apenas por meio da frequência "no caso de disciplinas cuja frequência às aulas é a única forma de avaliação". (Regimento Geral da Graduação, Capítulo II, Seção I, grifo nosso). Para "Educação, Corpo e Arte", a frequência é apenas um dos quesitos, não o único. 


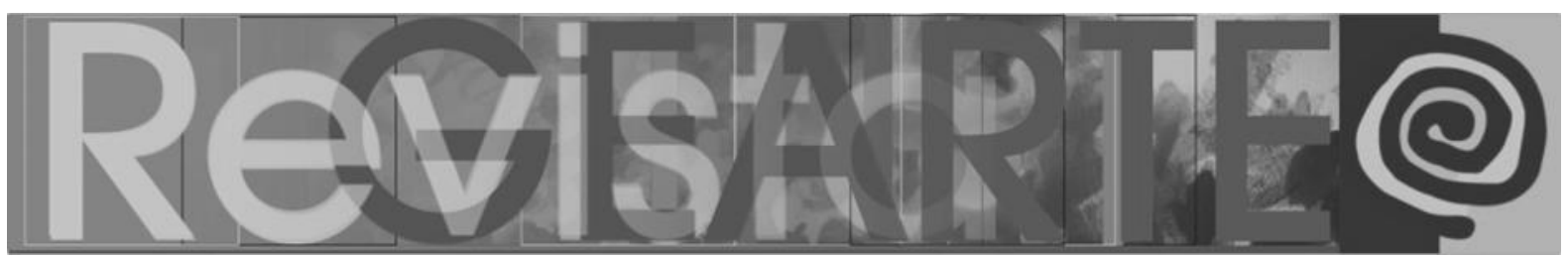

Por considerar relevante a presença física e a participação efetiva de estudantes nas aulas, proponho a revisão de um equívoco recorrente referente à inversão na forma de se compreender direitos e deveres na universidade. Muitos estudantes acreditam que "devem" usufruir do limite máximo de ausências a que "têm direito". Ora, o dever do estudante é estar presente em 100\% das atividades e, caso necessário, pode se ausentar em até $25 \%$ das aulas. Ao identificar o quanto essa atitude era um padrão de comportamento transmitido de uma turma à outra, passei a informar, logo no primeiro encontro do semestre que: 1) todas as aulas do curso são importantes; 2) cada encontro é único e exclusivo; 3) o vivido numa aula se encadeia na aula seguinte; 4) a participação de cada uma é singular e relevante na constituição do todo; 5) o êxito da disciplina depende da presença ativa e da integração das participantes; 6) a assiduidade e a pontualidade fazem parte da avaliação. Dessa forma, embora não chegue a consolidar $100 \%$ de frequência, diminui-se consideravelmente o número de faltas, o que representa um ganho significativo ao se ter um único semestre de arte em toda formação.

Criar mecanismos administrativos e acadêmicos que obriguem estudantes a cursarem presencialmente e a participarem ativamente da disciplina de arte na Pedagogia pode ser visto como uma atitude que vai na contramão do pensamento artístico, ou ainda, parecer algo totalmente descabido. Apesar de todos os questionamentos e de tensões vividas, afirmo que tem valido a pena. A título de exemplo, gostaria de destacar duas situações delicadas que foram enfrentadas ao longo dos anos devido a essa posição.

A primeira, referente a uma dupla de estudantes que, em virtude de sua crença religiosa, não podiam mexer o corpo de forma alguma, isto é, não podiam dançar nem cantar. Quando tomaram conhecimento de que essas duas ações faziam parte do conteúdo do curso, a dupla entrou com pedido junto à coordenação de graduação para a realização de "exercícios domiciliares". Ocorre que o vetor de carga horária da disciplina como "Atividade de Laboratório" (código L) não permitia a realização de exercícios domiciliares. Nos casos previstos por lei, como licença saúde ou licença maternidade, licenças essas que têm tempo de duração, a 


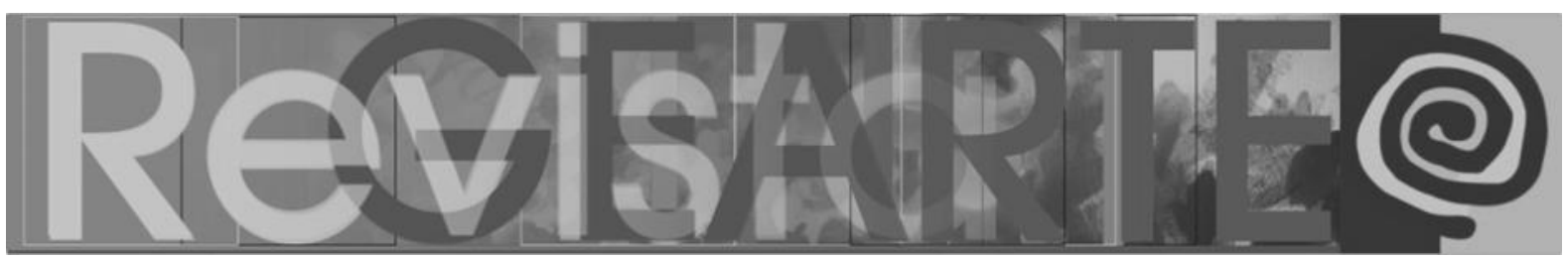

orientação dada às solicitantes é que se matriculem no semestre seguinte, assim que concluído o tempo de reclusão. Não era o caso da dupla. Não se tratava de questão de saúde nem de maternidade. A questão era de ordem religiosa. Indignadas, ambas entraram com recurso anexando como justificativa para a não participação nas aulas, uma carta assinada pelo pastor do templo que frequentavam. A universidade pública reiterou ser laica. $O$ documento, sem valor legal, sequer foi avaliado. O recurso foi veementemente negado e elas tiveram de frequentar a disciplina e participar da criação cênica final (como analisaremos mais adiante). A presença da dupla, não sem atritos e constantes questionamentos nas aulas, levou a turma a importantes discussões. À época, acreditava que apenas as duas estudantes lograriam com a situação e iriam refletir sobre o papel da professora na educação infantil, mas ao final, a turma toda lucrou muito com as reflexões que afloravam a cada contestação delas sobre o repertório de canções, histórias e contos, sobre os jogos e as brincadeiras, sobre o quanto o corpo tanto da professora quanto da criança comunica e expressa. Isso só foi possível devido à presença de todas na sala.

O segundo caso que gostaria de destacar foi relativo a uma aluna da Pedagogia do período noturno que, vítima de um AVC, encontrava-se com um lado do corpo paralisado e necessitava do auxílio de familiares para se dirigir à universidade. No primeiro dia de aula, acompanhada por sua filha, uma jovem de 22 anos, tentou argumentar que era um grande sacrifício se deslocar para participar da disciplina e pedia, encarecidamente, para ser dispensada, mesmo ciente de que o vetor de carga horária (código $L$ ) demandava sua presença. $\mathrm{O}$ que ela propunha, na verdade, era um contrato de gaveta, isto é, uma maneira de burlar as regras acadêmicas. Ouvi atentamente todos seus argumentos e pedi que assistisse àquela aula para, então, compreender as razões que me levavam a fazer questão da presença de todas. Embora contrariada, permaneceu na sala e participou do primeiro encontro, no qual expliquei que cada uma iria participar à sua maneira, respeitando seus limites individuais e que o mais importante era tentar fazer o que era proposto. Ela voltou na semana seguinte e participou do 


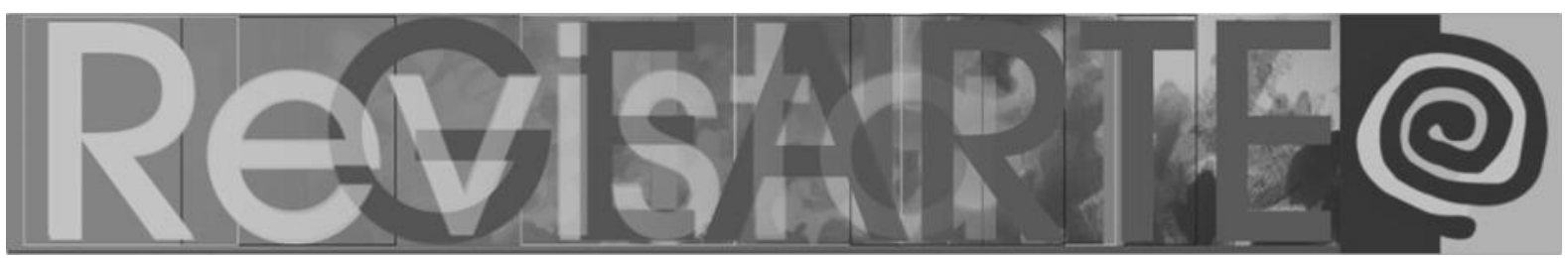

segundo encontro, depois do terceiro, do quarto e assim por diante. Foi a aluna mais assídua da turma. Não apenas ela, sua filha também, literalmente, entrou na roda. No momento da avaliação final do semestre, ela foi a primeira a falar. Disse que contava nos dedos quantos dias faltavam para ir à Unicamp, que aguardava ansiosamente a chegada da quinta-feira, dia da aula de "Educação, Corpo e Arte", dia de encontrar com as colegas, de dançar, de cantar, de criar com o corpo. Em suas palavras, "o único dia da semana em que se sentia, finalmente, viva!".

Silêncio tomou conta da sala.

Esses dois relatos, dentre tantos outros, acabam por sinalizar a importância de a disciplina "Educação, Corpo e Arte" ser obrigatória no curso de Pedagogia e o quanto foi correta e eficaz a decisão de se definir para ela o vetor de carga horária como "Atividade de Laboratório" (código L), exigindo a presença física e ativa dos indivíduos. À época, uma decisão que foi alvo de críticas por parte de colegas e algumas estudantes, porém, que reafirmou que o conhecimento que se adquire nessa disciplina é tácito, depende de experimentação e de vivência, sobretudo no coletivo. Mais do que isso, as situações acima relatadas, somadas a várias outras, têm reafirmado a importância de se defender a presença física e a frequência como um dos quesitos para se avaliar em arte.

\section{Inspiração, ação e criação}

Se o conhecimento em arte é construído na prática, na ação e na criação, ele deve ocorrer no processo de avaliação em arte. No caso da disciplina "Educação, Corpo e Arte" trata-se de um processo contínuo, que leva em consideração a frequência, como acima apontado, e a participação nas atividades práticas e criativas que acontecem em absolutamente todos os encontros.

A disciplina é estruturada em duas partes. Na primeira, temos: a) "pitadas de arte", por meio de provocações poéticas (como veremos a seguir); b) "pondo a mão na massa", em que ocorrem experimentações e vivências corporais, com dança, música, jogos teatrais, improvisações, em duplas, trios e todo grupo. Ao 


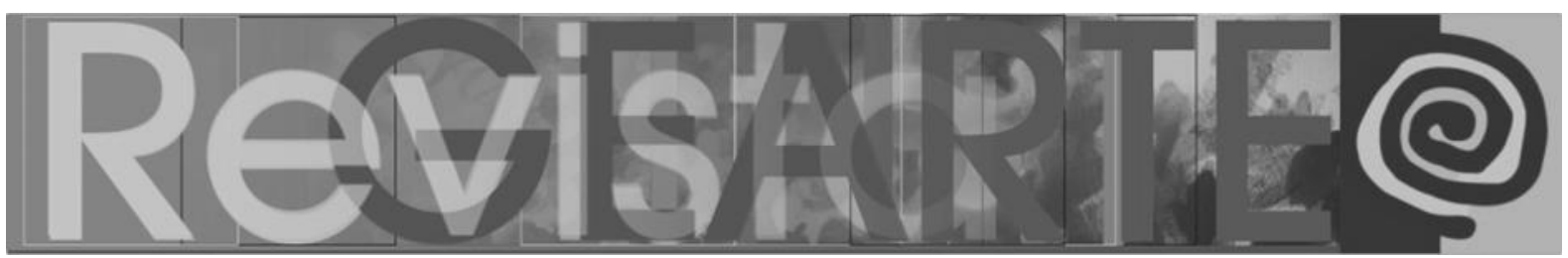

final da primeira parte, como preparação para o trabalho subsequente, a turma é subdividida por mim em grupos de sete a dez participantes. A ideia é buscar a cada encontro trabalhar com pessoas diferentes e, assim, provocar desafios e aprendizados constantes. Após o intervalo, a segunda parte se inicia com os grupos formados e segue com: a) "criação coletiva", com a elaboração de uma cena com começo, meio e fim, sobre um tema dado a priori; b) "apresentação e apreciação" das criações coletivas, momento em que o grupo mostra sua produção e assiste ao resultado dos demais grupos; c) "reflexão", na qual ocorre a análise das cenas com discussão geral sobre a aula; e d) dança circular de encerramento do encontro.

Afirmo com certa frequência, seja em aula, seja nas palestras que ministro, que da mesma forma como não é possível aprender a nadar fora d'água (seja piscina, rio, lago ou mar) não é possível aprender arte sem fazer arte; logo, para aprender a nadar é preciso se molhar e para aprender arte é preciso se sujar. Essa afirmação parte de duas analogias. A primeira, relacionada ao meu projeto de pesquisa intitulado "Imersões Poético-Acadêmicas como processos de formação do Artista-Pesquisador-Docente" ${ }^{\prime \prime}$. Nele defendo a necessidade de se estar imerso dentro de um fazer artístico para se construir conhecimento de/em arte. A segunda analogia é inspirada no slogan - "se sujar faz bem" - que foi veiculado em 2015 dentro da campanha publicitária de um sabão em pó. Ao relembrar o leitor sobre essa publicidade, o que quero destacar não é a importância das brincadeiras para o desenvolvimento pleno da criança. Sobre isso, vários pesquisadores da educação infantil já falaram, inclusive a própria empresa de sabão ${ }^{8}$ Meu objetivo aqui é destacar que, se para o crescimento saudável da criança ela precisa pôr a mão na massa, na tinta, na lama, ao experimentar com o próprio corpo e ao vivenciar os diferentes sentidos se sujando muito; para se aprender arte também. A diferença entre uma situação e outra é que após uma aula de arte, a "sujeira" impregnada na pessoa não sai mais. Não se sai ileso de uma boa aula de arte, pois arte mexe com as pessoas, deixa marcas, manchas e não há "sabão em pó" que tire isso! 


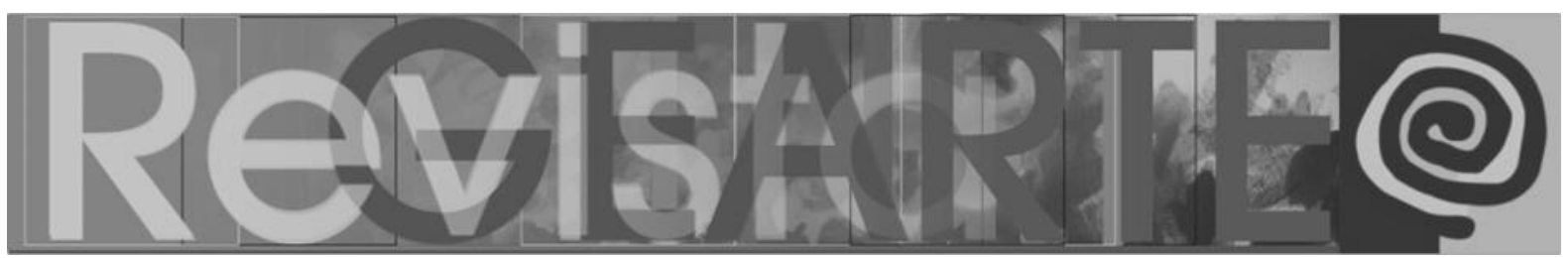

A cada aula da disciplina "Educação, Corpo e Arte" é levada em conta as características, expectativas e dificuldades de cada estudante, isto é, as participantes respondem de acordo com suas reais possibilidades, capacidades e limites. Considerar os limites de cada estudante do curso de Pedagogia foi um aprendizado para mim. Acostumada a trabalhar com atores e dançarinos profissionais antes de ingressar como docente na Faculdade de Educação, trazia para a sala de aula uma expectativa em relação às respostas corporais e comportamentais das participantes, e essa expectativa teve de ser redimensionada com o apoio de colegas que atuavam junto à formação de professoras há mais tempo. Sobre isso, escrevi em meu memorial de livre docência:

Numa das primeiras vezes que atuei junto à EP 158 [Educação, Corpo e Arte], acostumada a trabalhar com estudantes de teatro e de dança, entrei em atrito com a turma de pedagogia, pois, do meu ponto de vista à época, os estudantes não levavam a sério minhas propostas. Riam o tempo todo e ficavam falando entre si ao invés de realizarem o movimento pedido. Levei um tempo para entender que o riso e a conversa paralela eram nervosismo, não falta de interesse ou desatenção. [...] Segui o conselho de Ana Angélica Albano e ao invés de interpelar os estudantes exigindo deles respeito às atividades, silêncio e disciplina, passei a seduzir com a arte, com a minha forma de expressão. (STRAZZACAPPA, 2015, p. 25).

Daquele momento em diante, decidi iniciar as aulas com uma provocação poética, isto é, passei a usar os primeiros minutos para trazer para a sala de aula pitadas de arte, seja por meio da leitura de um poema, da representação de uma cena, da contação de uma história ou da intervenção de um clown. A princípio, a ideia era "seduzir com a arte" para que esta servisse de inspiração para as estudantes. No entanto, essas pequenas intervenções foram além do objetivo primário de "povoar o imaginário daqueles estudantes com outras imagens, sons e possibilidades cênicas". (STRAZZACAPPA, 2015, p. 25). Em alguns casos, representavam uma das poucas oportunidades de contato com as artes cênicas por parte de certas estudantes. Atrasos passaram a ser evitados, pois as estudantes não queriam de forma alguma perder o primeiro momento da aula em que era instaurado um "estado de arte", afinal, elas nunca sabiam o que iria acontecer: se um poema, uma história, uma dança ou se a Dona Clotilde ${ }^{9}$ iria aparecer. A maneira como chegavam para a aula mudou. As estudantes se 


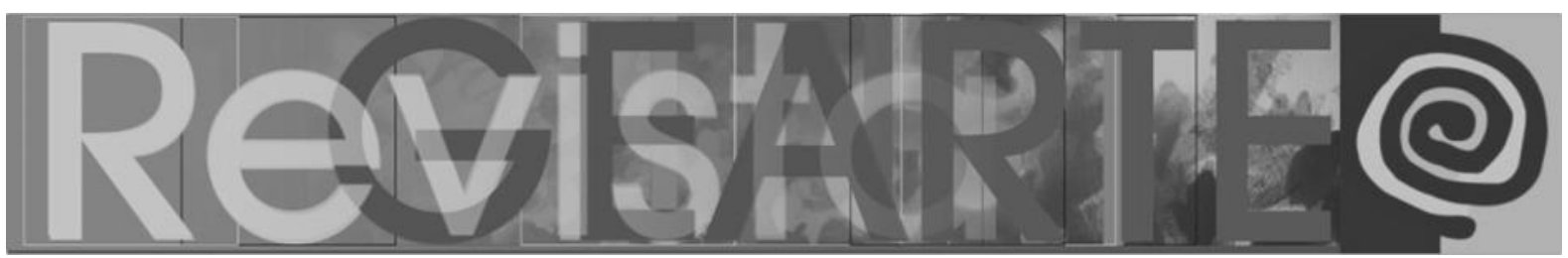

apresentavam em sala num estado diferente, com olhos e ouvidos abertos, mas principalmente, com a mente e o coração prontos para a contemplação. Mesmo sendo pitadas de 5 a 10 minutos, no máximo, esse curto espaço de tempo se mostrou como um importante ingrediente constituidor de um ambiente propício para a arte entrar.

Ao longo das ofertas da disciplina, fui assimilando os diferentes tempos de compreensão e de resposta em relação à ação criativa. Daí decorre a necessidade de levar em consideração, na avaliação, os vários momentos do processo. Lembro-me, por exemplo, de uma estudante que demonstrou a enorme habilidade com fios e linhas para confeccionar um boneco de pano (numa atividade inspirada no Bunraku10) mas nenhuma coordenação para articulá-lo depois de pronto. Diferente da colega de grupo, com grande dificuldade com trabalhos manuais, absolutamente tímida, cuja voz mal era ouvida, mas que surpreendeu a todas da turma quando deu vida ao seu boneco e o fez cantar!

Lembro-me, ainda, de um rapaz numa atividade de improvisação em dança que, apesar de todas as tentativas para que ele se deslocasse no espaço, envolvesse outras partes do corpo na cadência e se juntasse a outros colegas, ficou o exercício todo parado no lugar com os olhos fechados, movendo apenas os braços.

Qual não foi minha surpresa [findo o exercício] ao ver que ele foi o primeiro a falar. Por alguns segundos acreditei que ele iria reclamar da atividade ou relatar sobre sua dificuldade de entrar na dança. Mas não. Seu comentário foi exatamente oposto. Manifestou sua satisfação de ter dançado pela primeira vez na vida! (STRAZZACAPPA, 2015, p. 26)

Por vezes, o que não passa de uma gota para um, é um oceano para outro!

Como em processos de criação arte não existe certo nem errado ${ }^{11}$, existem caminhos a serem trilhados e a expressão de cada estudante, aprendi a não as subestimar e passei a respeitar ainda mais as experiências corporais individuais das estudantes. Como nem todas participantes se manifestam oralmente em aula, seja por timidez, seja pelo número grande de matriculadas, adotei o princípio do 


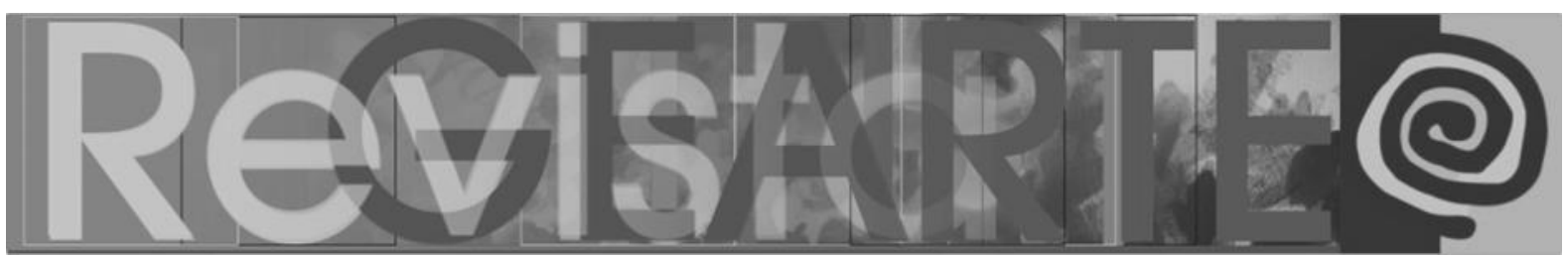

registro de processos que, ao longo dos anos, já teve várias denominações (caderno de anotações, diário de bordo, portfólio de artista-professor) e formatos (produzido por textos, por desenhos, por fotos e por áudios). Certa vez, ao invés de caderno, solicitei às estudantes uma caixa individual na qual a cada dia fosse depositado um objeto que simbolizasse ou representasse a experiência vivida no encontro. Ao final do semestre, como parte do trabalho final individual, elas poderiam escolher um dos objetos dentro da caixa e criar algo a partir dele, ou então, quem quisesse, poderia apresentar o conteúdo total da caixa. Várias optaram por abrir a caixa e revelar os segredos nela contidos. Uma experiência ainda a ser descrita!

\section{Apresentação, apreciação e discussão}

A criação coletiva acima mencionada é elaborada em 20-30 minutos a partir de um determinado tema. A cada aula, sugiro um diferente mote propulsor, que pode ser concreto, como manchetes de jornal e objetos (chapéu, caneta, celular, livro, chaveiro, dentre outros) ${ }^{12}$, ou abstrato, como cores, emoções (alegria, tristeza, medo, angústia, saudades) e ditos populares ${ }^{13}$. Depois de preparada a cena, os grupos apresentam suas produções às demais colegas da turma. Todas passam pela condição de artista e de plateia, pois o aprendizado ocorre nas duas situações, tanto na produção da própria cena quanto na contemplação da cena alheia. Assim, na condição de artista, aprende-se a planejar, discutir, fazer, criar, ensaiar, mostrar, superar vergonha, controlar ânimos, improvisar, achar soluções, dentre outras. $\mathrm{Na}$ condição de plateia, aprende-se a observar, olhar, calar, apreciar.

Sempre, após as apresentações, ao final de cada aula, realizamos uma discussão sobre as impressões, sensações e emoções a partir do que foi visto, apreciado e compreendido de cada cena. A discussão se dá em círculo, de forma que todas as pessoas possam ver e serem vistas, ouvir e serem ouvidas. Como aponta uma ex-aluna da Pedagogia citada por Fang (apud ALBANO, 2019): 


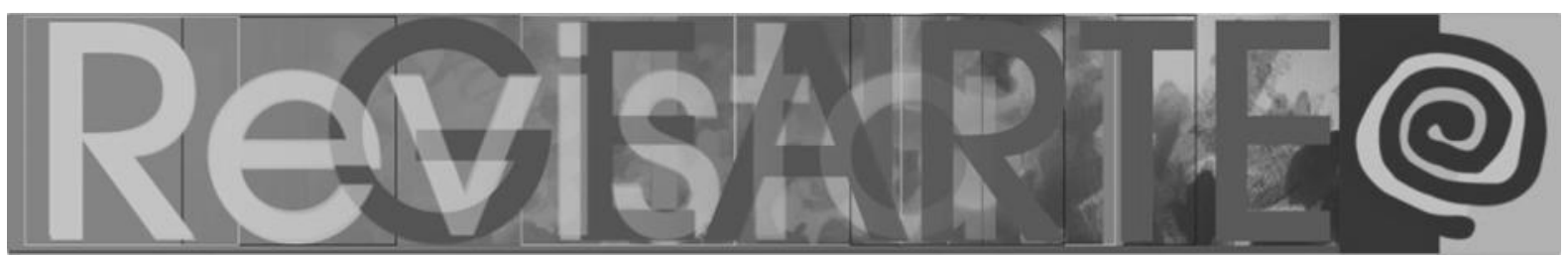

A roda proporcionava a inserção, tanto individual quanto coletiva no espaço de aula como acontecimento, pois ao mesmo tempo em que eu ocupava um lugar de reflexão individual, estava totalmente inserida no olhar dos outros. Quando contava minha história o diálogo acontecia em todas as direções, não somente para a professora em si, como geralmente acontecia nas outras disciplinas curriculares. (FANG apud ALBANO, 2019, p. 131).

Essa reflexão no coletivo também é parte constitutiva do aprendizado, momento em que se discute, inclusive, sobre o próprio ato de avaliar arte. Afinal, para se avaliar é preciso aprender a comentar, a tecer críticas, a comparar, a analisar, a argumentar, todas ações que lhes serão demandadas uma vez professoras.

Seguindo a sequência das apresentações dos grupos, iniciamos tecendo comentários sobre a primeira cena do dia/noite. Nesse momento, quem se apresentou não pode falar. Ao contrário, deve ouvir os comentários, críticas e elogios, captar as sensações e percepções daquelas pessoas que assistiram à sua cena. Embora muitas vezes membros do grupo que está no foco fiquem tentados a falar, indago que não cabem explicações nem justificativas. As estudantes devem ouvir caladas, acatar os comentários e refletir sobre eles. Procedemos assim com cada grupo, emitindo e ouvindo comentários sobre o segundo, o terceiro e o quarto grupo. Somente findadas as apreciações de todos os grupos é que passamos à segunda rodada, momento no qual quem se apresentou, enfim, pode falar. Sugiro que iniciem focando seus comentários no que foi dito pela plateia sobre sua produção, arguindo e contra-argumentando, para, só então, num segundo momento, narrar um pouco sobre os bastidores da montagem, revelando as ideias que surgiram, as dificuldades que tiveram e as soluções encontradas.

Essa ordem de discussão é proposital. O objetivo é evitar o primeiro impulso que ocorria ao se abrir a discussão, qual seja, se desculpar ou se justificar por algo que, de seu ponto de vista, havia dado errado na cena, ou pior ainda, procurar culpados pela suposta falha. Ocorre que para a plateia, tudo o que foi apresentado era novo. Assim, de nada adiantava ficar discutindo sobre algo que simplesmente não acontecera. Esse tipo de discussão, sobre erros e acertos, funciona 


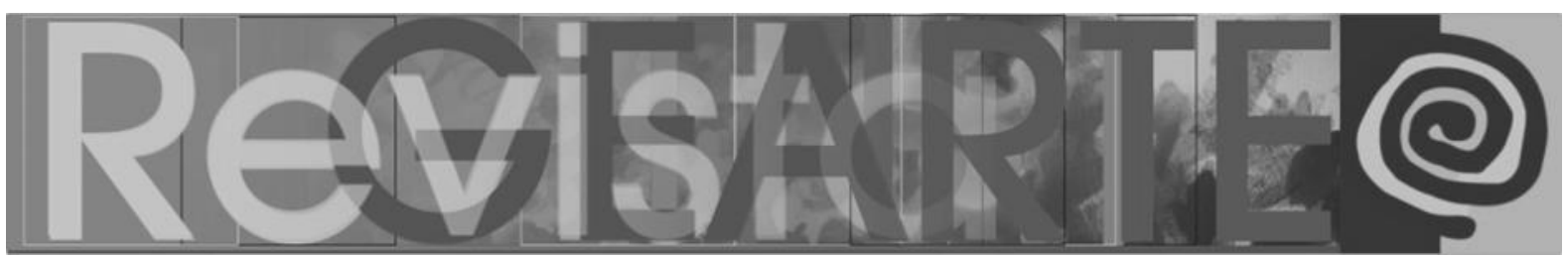

internamente ao grupo para o aprimoramento da cena para apresentações futuras. Não era o caso. As cenas produzidas nas aulas tinham por propósito trabalhar a criação coletiva a partir de um determinado tema, proporcionando o desafio de, em pouco tempo, um grupo de pessoas diferentes entre si construir uma ideia e encontrar uma forma de comunicá-la por meio de uma cena, com ou sem palavras. Da parte do público, o intuito era, a partir da primeira impressão ao assistir a cena, analisar o resultado encontrado tendo como ferramentas para essa análise o repertório de cada um.

Ao longo do semestre, fui percebendo nitidamente a mudança de postura das estudantes na construção das cenas e na forma de realizar a análise das apresentações. Comparava esse aprendizado com o aprimoramento da escrita. Todas as estudantes produzem textos e mais textos nas diferentes disciplinas teóricas que cursam durante sua formação. Se é a partir da crítica a um texto escrito que posso melhorar minha redação, independente do assunto da resenha, o mesmo ocorre com a produção em artes cênicas. É a partir dos comentários e críticas sobre as cenas apresentadas que se pode ir aprimorando a forma de se comunicar por meio da linguagem cênica.

Assistir e comentar as cenas das colegas são ações que podem auxiliar, inclusive, na ampliação de seu repertório que, majoritariamente, costuma ser limitado e/ou viciado em modismos. De fato, as participantes trazem de suas experiências anteriores (escolares ou familiares) um conceito estético de cena que se apresenta como um desafio para nós, professoras de arte: como romper com uma ideia preconcebida de teatro e de dança? Romper com os "teatrinhos" e as "dancinhas" cujos figurinos (que muitas insistem em denominar como "fantasia") e cenários são produzidos com sucatas e/ou EVA? Como conseguir fazê-las abrir mão da música da moda? Enfim, como afastar as futuras professoras do senso comum? Como mostrar que a arte é polissêmica por natureza? Que podem ser múltiplas as leituras de uma mesma montagem? 


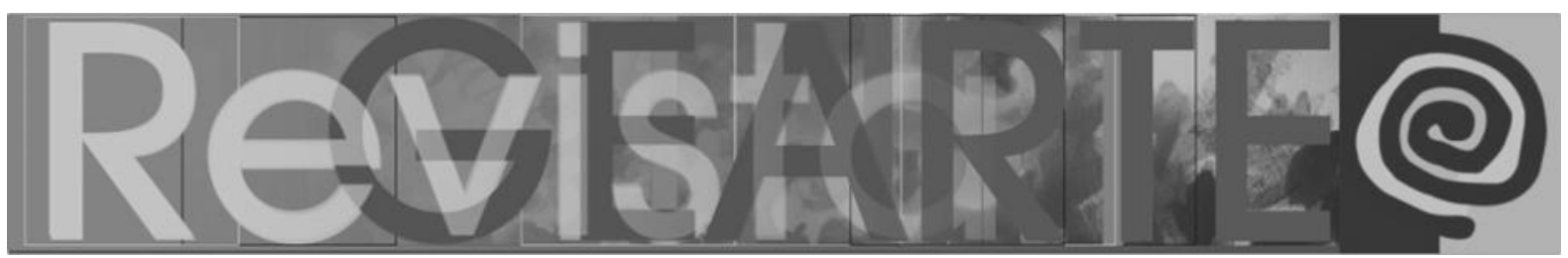

Por vezes, um grupo realizava ao final da aula uma encenação marcante, surpreendendo o público a ponto de gerar suspiros. Quando isso acontecia, perguntava imediatamente se elas eram capazes de identificar o que as levou àquela reação. Concluo que, da mesma forma que as estudantes chegam com uma estética "escolar" (na falta de um nome melhor), também são capazes de admirar aquilo que não é óbvio. É neste momento que, na função de professoras mediadoras, temos de ajudar as estudantes na construção do olhar. Apontar justamente para aquilo que elas próprias se admiraram, mostrando-Ihes que elas têm um senso estético para além daquilo que tem sido ofertado seja pela mídia, seja pela educação que tiveram até então.

Na disciplina "Educação, Corpo e Arte", além da participação nas atividades propostas em sala de aula e nas pequenas produções e reflexões coletivas ao final de cada encontro, além das anotações individuais poéticas ou concretas (objetos na caixa), as estudantes devem apresentar como avaliação final do semestre uma cena elaborada sobre um determinado tema de livre escolha. A cena deve ter começo, meio e fim e ser produzida de forma coletiva, com a presença de absolutamente todas as participantes do grupo.

Diante de turmas com uma média de 45 estudantes, solicito grupos com, no mínimo, nove participantes. A justificativa para tal número está na importância de se aprender a trabalhar no coletivo. Duplas, trios, quartetos e até quintetos não apresentam grandes desafios. Porém, trabalhar em grupos com mais de sete integrantes começa a ser muito mais instigante. Grupos maiores aglutinam mais opiniões e, com isso, integrantes são obrigados a aprender a arguir para defender sua ideia, ao mesmo tempo, devem aprender a ouvir a ideia alheia. Grupos maiores também tendem a juntar líderes e, com isso, algum líder terá de ceder. Essa condição gera momentos de grande aprendizagem: aprende-se a falar e a calar para ouvir o outro; aprende-se a ouvir e escutar; aprende-se a expor uma opinião e a acatar a decisão da maioria. Outro aspecto para esse número é de cunho prático. Com nove pessoas por grupo, ter-se-ia no máximo cinco apresentações por turma, que é um número razoável de cenas a serem assistidas num único dia. 


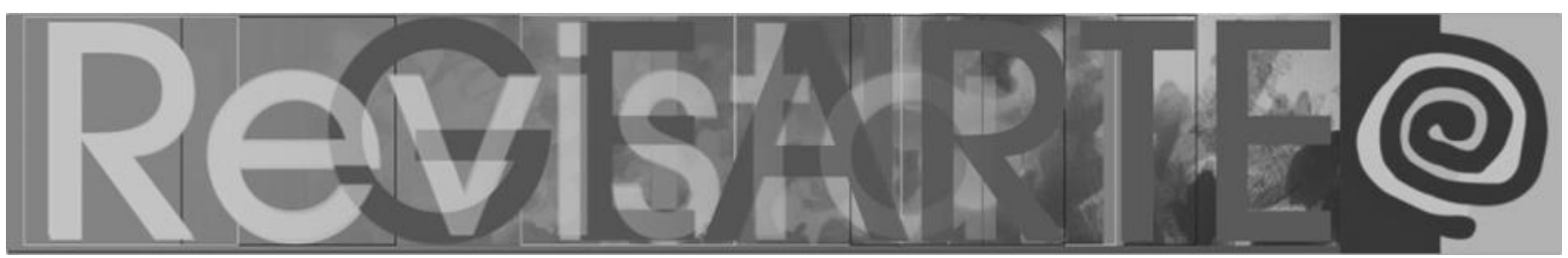

Outra exigência para a apresentação final é que todas as participantes do grupo estejam em cena, na condição de corpos presentes, atuando, seja como personagens, cantoras, contadoras de história, dentre outras. Explico que caso haja a necessidade de um aparato técnico, como iluminação (sobretudo para as turmas do curso noturno), sonoplastia, efeitos especiais e/ou tecnológicos, o grupo deve solicitar apoio a uma pessoa externa ao grupo ou mesmo externa à turma.

Uma última recomendação é que a cena deveria ser ensaiada anteriormente, diferentemente daquilo que estavam habituadas ao longo do semestre em que as cenas eram pensadas em 20-30 minutos e mostradas aos colegas imediatamente após sua construção, quase no improviso. Para a apresentação final, a cena deveria estar completa no momento da apresentação, com figurino, cenário, adereços, tecnologia e o que mais houver.

Por ser profissional do campo das artes cênicas, desde a época em que a disciplina era compartilhada entre várias docentes, ficava responsável pela explicação deste processo final de avaliação, tendo em vista a aproximação desta atividade com a produção de um espetáculo, embora ao longo dos anos, já tenhamos tido grupos que montaram instalações artísticas e outros que apresentaram vídeos.

A cada final de semestre, uma euforia tomava conta da sala. Os preparativos antes da apresentação, com a entrada e saída de estudantes carregando caixas com figurinos e cenários. Do lado de fora da sala, a presença de familiares, de amigos e de estudantes de outros cursos da universidade. A seriedade dedicada à apresentação final da disciplina dava indícios da mudança de paradigma em relação ao ensino de arte. Produzir arte demanda engajamento, vínculo e repetição; demanda respeito e responsabilidade tanto com as colegas do grupo, quanto com a plateia; produzir arte demanda tempo. 


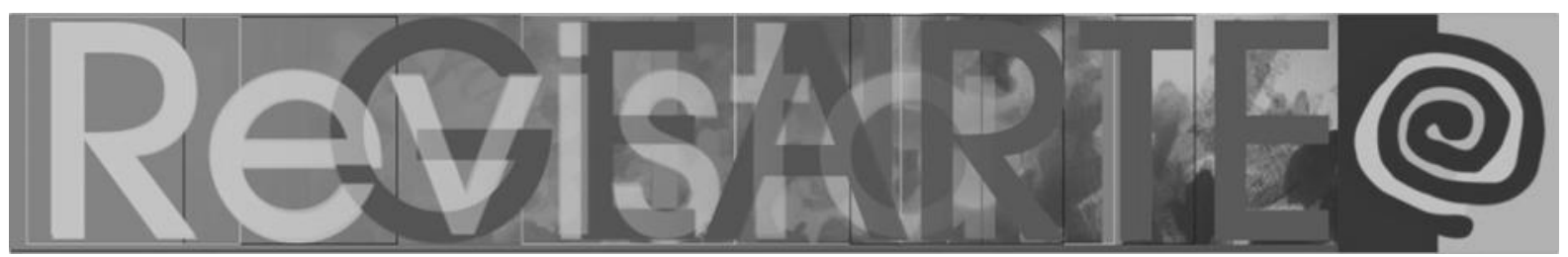

Nestes 20 anos ministrando a disciplina de forma individual ou compartilhada com colegas docentes, as turmas sempre nos presentearam com trabalhos finais sensíveis, bem elaborados e tocantes.

Abro parênteses, no momento, para comentar o que ocorreu com a dupla de estudantes, que, por conta de sua crença religiosa, não queria sequer participar da aula, quanto mais estar em cena na apresentação final. Ambas se superaram. Primeiro, por vencerem a dificuldade de encontrar um grupo para trabalhar (grupos com nove pessoas, no mínimo); segundo, pela capacidade criativa de, coletivamente, encontrarem uma solução para estar em cena sem serem vistas. A apresentação foi surpreendente. O grupo lançou mão de luz negra e, usando roupas pretas dos pés à cabeça, calçaram meias e luvas brancas e, ao som de uma música, manipularam objetos brancos. Dentre esses objetos, cordas, bolas e um bambolê. Assim, os corpos não apareciam, apenas mãos, pés e os objetos brancos. Todas estavam em cena, articulando os objetos, porém seus corpos não eram vistos. O mais impressionante, no entanto, foi a revelação feita no momento da discussão final. O bambolê que roubou a cena, havia sido girado na cintura de uma das garotas da dupla. Ela estava radiante com os elogios recebidos, com a repercussão de sua atuação e por ter participado dessa experiência. $E$ isso tudo só foi possível graças a exigência de presença nas aulas e na apresentação final da disciplina "Educação, Corpo e Arte". Fecho parênteses.

Lembro-me perfeitamente do grupo que elaborou uma cena de circo, na qual cada estudante assumiu um número de picadeiro, com direito a mágico, domador de leão e o leão (cuja juba era um tutu de balé de criança colocado ao redor do rosto), malabarista, equilibrista, entre outros. A singeleza da forma como criaram e incorporaram os diferentes personagens foi encantadora. Houve um grupo que nos transportou para os anos 1950 e apresentou um estúdio de rádio durante os bastidores de uma radionovela. Houve ainda um grupo que fez uma releitura de um ritmo brasileiro, a Catira ${ }^{14}$ (ou Cateretê), transformando-a numa dança de roda conduzida só por mulheres. A cada final de ano ficava a me perguntar: seria possível se maravilhar novamente? 


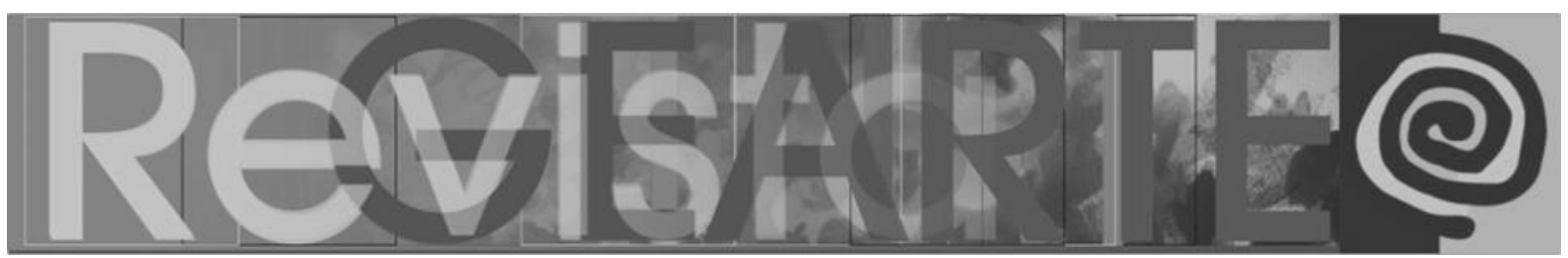

A resposta é sim. Gostaria de descrever uma das apresentações que colocou em cheque uma de minhas premissas referente à necessidade de se dividir a turma em grupos para que as apresentações tivessem sempre um público. Ideia essa pautada na própria compreensão de teatro como um espaço vazio que é atravessado por alguém enquanto o outro o observa, logo, que demanda no mínimo a presença de duas pessoas, uma que age, artista e outra que observa, espectadora (BROOK, 1994; BOAL, 1991).

A apresentação a qual me refiro ocorreu em 2014 na turma de Pedagogia matutina. Ao chegar diante da porta da sala, todas estavam ocupadas com os preparativos. Havia pedido a lista com os nomes das integrantes de cada grupo e a sequência das apresentações. Afirmaram que devido a problemas na impressora da faculdade iriam providenciar a lista posteriormente. Assim, entrei na sala sem saber quantos grupos seriam. Algumas estudantes já estavam em cena com guarda-chuvas em mãos. As demais estavam sentadas formando um semicírculo, algumas vestindo roupas pretas, outras com uma forte maquiagem no rosto. Nessa rápida observação, concluí que se tratava de três grupos e já fiquei satisfeita, afinal, eram grupos numerosos. Sentei-me no lugar indicado por uma aluna e, na condição de docente responsável pela disciplina, indaguei quando iriam começar.

Silêncio. De repente, uma música começa, e o grupo com os guarda-chuvas abertos se posicionou formando um muro. Ao ritmo da música clássica que tocava, o muro de sombrinhas coloridas começou a vibrar e foi se desfazendo. Cada pessoa com sua sombrinha ia sendo levada pelo vento, saia da cena e se sentava junto à plateia. Quando todas se foram, revelou-se uma segunda cena em que três bonecas de pano, interpretadas por estudantes, estavam largadas no chão e passaram a ser manipuladas por pessoas vestidas de preto para ganhar vida. As bonecas se levantaram, dançaram e caminharam em direção à plateia, convidando-a para dançar junto. As pessoas do público responderam ao convite e entraram na dança. De repente, uma estudante chamou a atenção de todos perto da porta, apontando para algo que acontecia do lado de fora. Nessa hora, o grupo que ainda estava sentado começou a se levantar aos poucos e a retirar a camiseta 


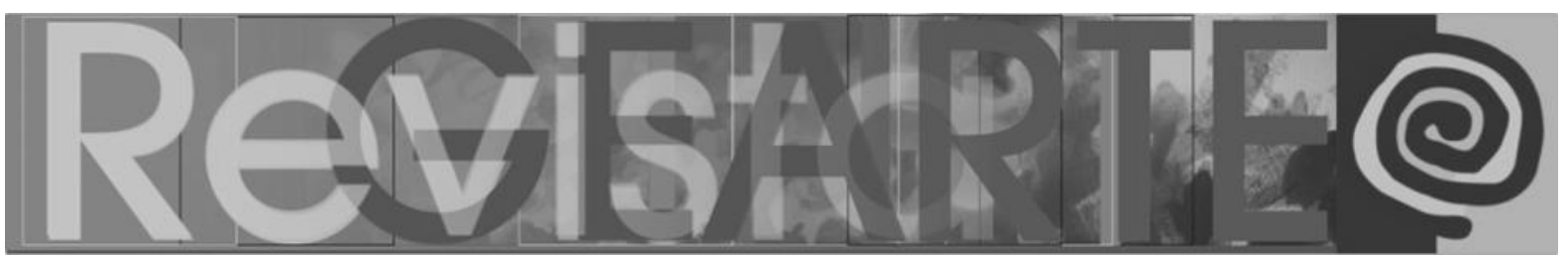

escura, revelando múltiplas cores como azul, amarelo, verde, laranja, roxo e vermelho. Todas começaram a cantar uma canção da Guiné-Bissau. Duas alunas me puxaram pelos braços para que as acompanhasse. Em fila indiana, caminhando e cantando pelos corredores do prédio, todas seguiram fazendo gestos repetidos com os braços como numa grande dança coral. Atravessamos o jardim de inverno, saímos pela porta da frente do edifício, descemos a rampa que conduz ao prédio principal da Faculdade de Educação. Formou-se um cânon ${ }^{15}$. Ao chegar na cantina da Faculdade, todas se colocaram ao redor de uma mesa na qual quatro alunas estavam sentadas, congeladas numa posição. Sobre a mesa, latinhas de refrigerante. Ao final da música africana, elas começaram a música percussiva "Batuque da Lata"16. Em seguida, elas se levantaram e puxaram uma roda em volta de uma frondosa árvore. Como éramos muitas pessoas, formaramse três círculos concêntricos e, todas juntas, dançamos o Zum Gali Gali ${ }^{17}$ Ao final, os círculos concêntricos se transformaram num grande abraço coletivo ao som dos aplausos de transeuntes e pessoas que estavam na cantina.

De volta à sala de aula, precisei retomar o fôlego. Aquela turma formada excepcionalmente por 54 integrantes havia criado uma cena coletiva com absolutamente todas as estudantes. Utilizaram vários dos repertórios apreendidos em aula, como músicas (da Guiné-Bissau, clássica e dos Barbatuques), Bunraku, dança circular, porém não de forma direta, simplesmente reproduzindo o que assimilaram, mas criando a partir deles. Por exemplo, o Bunraku foi feito com gente e não com boneco de pano; a dança coral foi feita dentro do espírito do "siga o mestre" em fila indiana e com deslocamento espacial; todas as participantes se propuseram e aprenderam uma canção em outra língua e criaram novos gestos (mais simples) para ela, para que fossem imitados rapidamente por aqueles que entrassem na fila; lançaram mão de explorar os mais variados espaços dentro e fora da sala de aula, corredores, jardins, rampa, cantina, bosque; a dança circular do Zum Gali Gali, com a qual sempre concluía minha aulas, foi readaptada ao espaço e à proposta cênica, sendo dançada em três círculos. Também destaco o uso de figurinos, pensados de forma a representar cada momento da cena. Do dia 


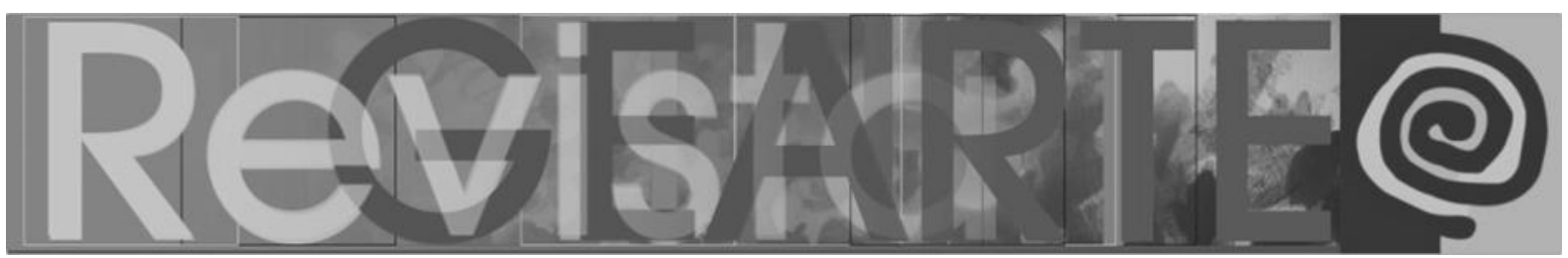

chuvoso, cinza e preto, com as sombrinhas que iam sendo levadas por um sopro de vento às cores das camisetas de todas as participantes ao final. Enfim, da concepção ao resultado estético, as estudantes dessa turma demonstraram a compreensão do fazer artístico.

\section{Concluindo}

Embora tenha me atido no presente capítulo a narrar com mais detalhes o resultante de uma apresentação que foi marcante por ter envolvido todas as estudantes em uma única encenação, não posso deixar de salientar que várias têm sido as surpresas, majoritariamente positivas, nas avaliações coletivas finais da disciplina "Educação, Corpo e Arte".

Com a presença na plateia de familiares e colegas de outros cursos da universidade, convocava a todos e todas para se integrarem na roda final e emitirem também seus comentários.

Alguns familiares não discorriam necessariamente sobre a apresentação em si, mas revelavam o quanto a família havia sido totalmente envolvida no processo, contribuindo na logística com seu conhecimento de tecnologia para a gravação de áudio ou com suas habilidades manuais, na produção de figurinos e acessórios. Houve casos em que familiares contribuíram efetivamente nos ensaios, fazendo a réplica do personagem ou mesmo a direção de cena. Esses comentários me ajudaram a ilustrar o quanto a criação em artes cênicas é, de fato, um trabalho coletivo. Um trabalho em que cada qual se responsabiliza por uma pequena parte em prol de um resultado comum maior. Enfatizava que realizar uma criação cênica poderia colaborar para se aprender, na prática, o que vem a ser um trabalho coletivo, tão necessário na escola.

Isso posto, explicava-Ihes sobre o quanto era importante para as estudantes ouvirem suas impressões também sobre a apresentação em si, pois suas apreciações contribuiriam para que tivessem uma melhor percepção daquilo que 


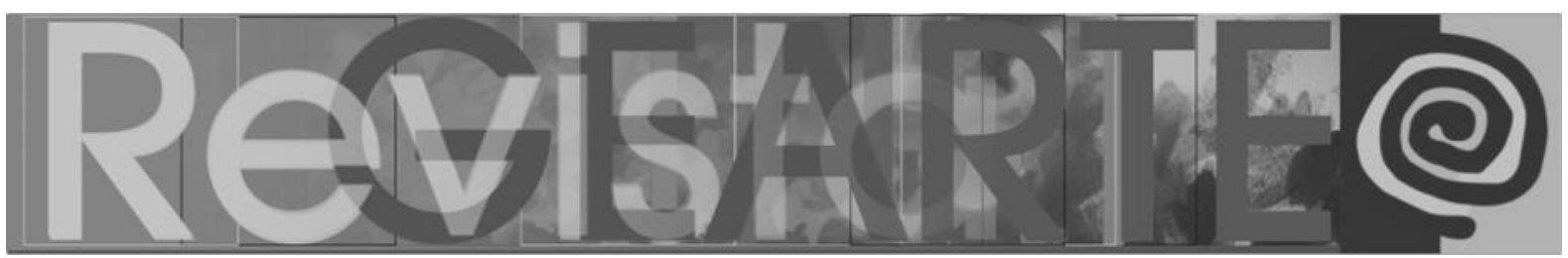

haviam comunicado por meio de suas apresentações cênicas. Destacava assim a relevância de suas falas, tendo em vista que traziam o frescor no olhar.

Interessante destacar, neste momento, a espontaneidade das falas que surgiam, que se assemelhavam aos primeiros comentários emitidos pelas estudantes no início do semestre, como "gostei", "não gostei”, "não entendi", "parece que...", entre outros. Para elas, evidenciava-se aí o quanto haviam amadurecido ao terem aprendido como e o quê olhar ao longo da repetição da estrutura da aula: criação, apresentação, apreciação, discussão.

Relevante também comentar sobre o espanto das estudantes, na condição de artistas, ao identificarem que algo que consideravam um lapso ou erro ocorrido na cena, havia passado despercebido para a plateia ou então, visto como uma solução inusitada.

Mas talvez o mais importante resultante das falas da plateia tenha sido as estudantes captarem as diferentes leituras feitas sobre a mesma cena, leituras essas que iam muito além daquilo que elas próprias haviam pensado no ato de criação. Neste momento, aproveitava as falas para apontar que haviam acabado de perceber aquilo que afirmava em aula: a arte é polissêmica por natureza. Mesmo que se parta de uma ideia preconcebida da cena, não se pode garantir a leitura que será feita de sua obra. Artistas não fazem ciência. Artistas não querem comprovar nada. Artistas fazem arte e, com isso, abrem as portas do imaginário.

Como futuras professoras que irão trabalhar os diversos conteúdos escolares, fico na expectativa de que ao vivenciarem a disciplina "Educação, Corpo e Arte" e ao passarem pela avaliação constante compreendida como parte do processo de aprendizagem tenham a clareza daquilo que cabe às ciências e daquilo que cabe ao ensino de arte e, com isso, valorizem a presença de ambos os conhecimentos de forma equilibrada na formação de crianças de zero a dez anos de idade. 


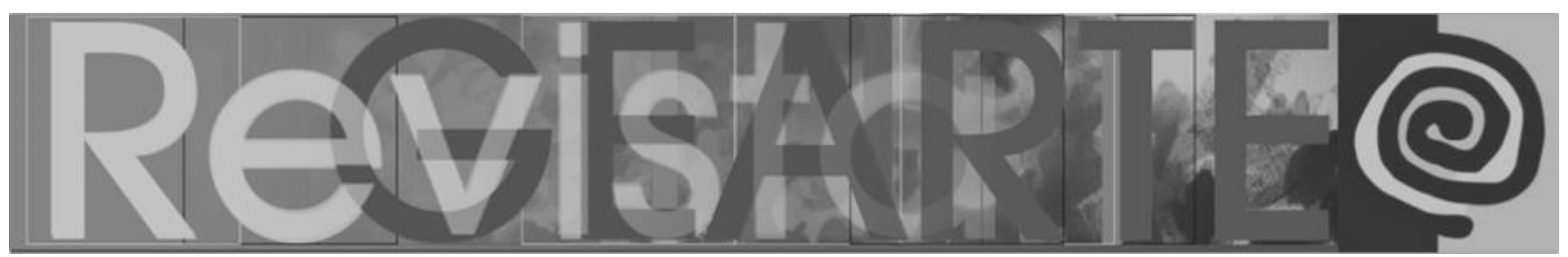

\section{Notas}

1 No presente artigo uso o feminino para me referir às professoras e às estudantes, tendo em vista que o curso de Pedagogia da Universidade Estadual de Campinas é majoritariamente constituído por mulheres.

2 Essa disciplina figura como uma das mais procuradas pelos estudantes dentro do Programa de Intercâmbio Acadêmico entre as Universidades Estaduais Paulistas (USP, UNICAMP e UNESP) assinado em 16/02/2000. O referido Programa permite que estudantes dessas universidades possam cursar disciplinas em outra universidade paulista (mediante vagas) e ter convalidados os créditos em sua instituição de origem. (http://143.107.26.205/documentos/intercambio_U niversidades_Estaduais_Paulistas_Acordo.pdf)

3 A lista completa das publicações encontra-se nas referências ao final do artigo.

4 Para o referido curso de especialização foram produzidos três livros (acompanhados por vídeoaulas) e distribuídos aos seis mil gestores do estado de São Paulo. O capítulo referente ao ensino de arte intitula-se "A construção do conhecimento em arte" (vide referências).

5 Vetor de Carga Horária: são parâmetros para a organização das atividades na disciplina, conforme disposto no artigo 27 (Regimento Geral da Graduação, Capítulo II, Seção I, Das Disciplinas, do Currículo Pleno e do Catálogo dos Cursos de Graduação).

6 No capítulo II do Regimento Geral da Graduação, "Da estrutura curricular", o item II do artigo 27 da Seção VI referente à Carga Horária das Disciplinas.

7 Pesquisa financiada com a bolsa de produtividade em pesquisa do CNPq.

8 A própria empresa de sabão convocou vários especialistas para escrever sobre o assunto, criou um site com os artigos e dicas de brincadeiras ao ar livre para crianças e produziu o que intitulou de "The World's First Dirt-Activated Book", o primeiro livro acionado por sujeira. (vide o link https://youtu.be/44zV9rohT1A).

9 Dona Clotilde é uma personagem clownesca que incorporo desde 2000. Trata-se de uma faxineira de origem humilde que não para em nenhum emprego devido ao fato de constantemente emitir suas opiniões e críticas.

10 Bunraku - tipo de teatro japonês do século XVII em que as personagens são vividas por marionetes de grande porte que, devido ao tamanho, são manipuladas por três pessoas visíveis à plateia. O primeiro manipula a cabeça e o braço direito, o segundo, o braço esquerdo, e o terceiro, os pés.

11 Embora exista certo e errado, mais ou menos eficiente quando se fala em aquisição de técnicas.

12 Objetos que podem (ou não) estar na cena em sua materialidade.

13 Como: "mais vale um pássaro na mão que dois voando"; "água mole em pedra dura tanto bate até que fura"; "em casa de ferreiro, espeto é de pau"; "gato escaldado tem medo de água fria", "quem não tem cão, caça com gato", dentre outros.

14 Dança típica do interior do Brasil (Goiás, Minas Gerais e interior de São Paulo), realizada majoritariamente por homens, sendo dois violeiros e dez dançadores, que, enfileirados, batem pés e mãos marcando o ritmo.

15 Na música, intitulamos cânon quando uma voz conduz a canção e é seguida por outra voz, que se inicia um pouco depois e é seguida por uma terceira voz, todas entoando a mesma canção, juntas, porém com atraso. $O$ exemplo mais conhecido entre nós é a canção infantil: "Frère Jacques".

${ }^{16}$ Música produzida pelo grupo de percussão corporal paulista Barbatuques (2008). Para maiores informações, vide: www.barbatuques.com.br. 


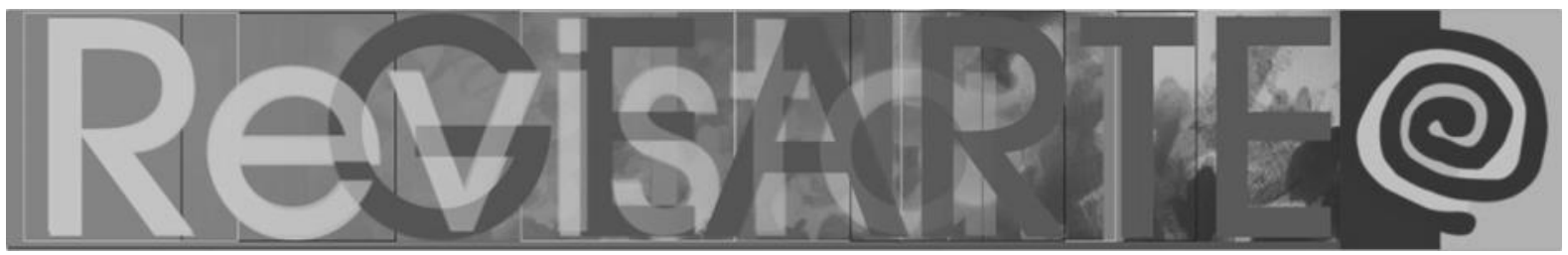

17 Trata-se de uma canção tradicional hebraica relacionada à criação do Estado de Israel. Alguns estudiosos acreditam que as palavras significam "somos todos um" numa corruptela de aramaico antigo. Em 2003, criei uma dança circular que venho divulgando desde então.

\section{Referências}

ALBANO, Ana Angélica. Conversas com jovens professores de arte. São Paulo: Loyola, 2019.

AYOUB, Eliana; STRAZZACAPPA, Márcia. Vivenciando o corpo e a arte: inovando na formação em pedagogia. In: SEMINÁRIO INOVAÇÕES EM ATIVIDADES CURRICULARES: EXPERIÉNCIAS NA UNICAMP, 1., 2007. Anais... Campinas, UNICAMP, 2007.

AYOUB, Eliana; STRAZZACAPPA, Márcia. Corpo e Arte: outras leituras na formação em pedagogia. In: COLE - CONGRESSO DE LEITURA DO BRASIL, 17., 2009, Anais... Campinas: UNICAMP, 2009.

AYOUB, Eliana; ALBANO, Ana Angélica; STRAZZACAPPA, Márcia. L` espace, le temps, le corps, le geste, l'autre, \art: éducation, corps et art dans la formation enseignante : éducation, corps et art dans la formation enseignante. In: COLLOQUE INTERNATIONAL EN ÉDUCATION, 4., 2017. Actes... Montréal, CRIFPE, 2017.

BROOK, Peter. L'espace vide. Paris: Seuil, 1996.

BOAL, Augusto. O teatro do oprimido e outras poéticas políticas. Rio de Janeiro: Civilização Brasileira, 1991.

HERNANDEZ, Fernando. Cultura visual, mudança educativa e projeto de trabalho. Tradução: Jussara Haubert Rodrigues. Porto Alegre: Artmed, 2000.

IAVELBERG, Rosa. Arte-educação modernista e pós-modernista: fluxos. 2015. Tese (Livre Docência em Formação de Professores) - Faculdade de Educação, Universidade de São Paulo, São Paulo, 2015.

IAVELBERG, Rosa. O professor em foco na arte-educação contemporânea. Revista GEARTE, Porto Alegre, v. 3, n. 1, p. 82-95, jan./abr. 2016. Disponível em: http://seer.ufrgs.br/gearte. Acesso em: 13 abr. 2021.

STRAZZACAPPA, Márcia; AYOUB, Eliana. Educação, corpo e arte: sensibilização à flor da pele. In: ENDIPE - ENCONTRO NACIONAL DE DIDÁTICA E PRÁTICA DE ENSINO, 13., 2006. Anais ... Recife: Lapa software, 2006.

STRAZZACAPPA, Márcia. A educação e a fábrica de corpos: a dança na escola. Cadernos CEDES, v. 21 , n. 53 , abr. 2001, p. 69-83.

STRAZZACAPPA, Márcia. Empilhando carteiras a procura de um espaço vazio. ABRACE Associação Brasileira de Artes Cênicas, Belo Horizonte, v. 9, n. 1, 2008. Disponível em: https://www.publionline.iar.unicamp.br/index.php/abrace/article/view/1418. Acesso em: 13 abr. 2021.

STRAZZACAPPA, Márcia. A arte como eixo na formação de professores. In: REUNIÃO ANUAL DA ANPED, 35., 2012. Anais ... Porto de Galinhas: Anped. 2012a.

STRAZZACAPPA, Márcia. Corpo em dança na formação de professores In: CONFAEB ARTE/EDUCAÇÃO: CORPOS EM TRÂNSITO. 22., 2012. Anais... Ponta Grossa, Universidade Estadual Paulista, 2012b. Disponível em: http://faeb.com.br/livro03/Arquivos/mesas/marcia strazzcappa.pdf. Acesso em: 13 abr. 2021.

STRAZZACAPPA, Márcia; SCHROEDER, Sílvia; SCHROEDER, Jorge. A construção do conhecimento em arte. In: BITTENCOURT, Agueda Bernardete; OLIVEIRA JUNIOR, Wenceslao Machado de. (Orgs.). Estudo, pensamento e criação. 3. ed. Campinas: Gráfica da FE, 2012. 


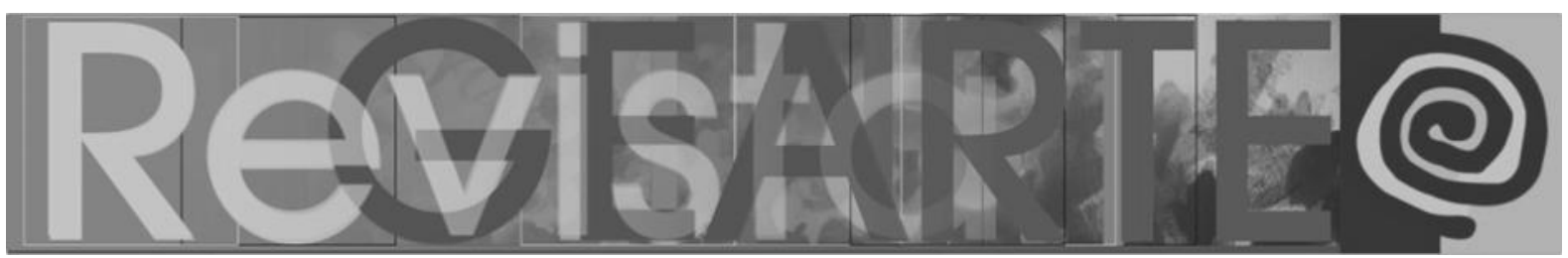

STRAZZACAPPA, Márcia. Sobre danças, andanças e mudanças: trajetórias e memórias de uma artista pesquisadora docente. Campinas: Librum, 2015.

STRAZZACAPPA, Márcia; PAGE, Christiane. L’expérience théâtrale dans la formation enseignante. In: COLLOQUE INTERNATIONAL EN ÉDUCATION, 4., 2017. Actes... Montréal, CRIFPE, 2017.

STRAZZACAPPA, Márcia. Pensando sobre o corpo (ou dando corpo ao pensamento) na formação de professores. In: MARTINS, Mirian Celeste; MOMOLI, Daniel; BONCI, Estela. (Orgs.). Formação de educadores: modos de pensar e provocar encontros com a arte e mediação cultural. São Paulo: Terracota, 2018.

STRAZZACAPPA, Márcia. Aos olhos do poeta, um copo vazio está cheio de ar. Aos olhos do professor, uma sala vazia está cheia de possibilidades. In: COLÓQUIO DA AFIRSE. 26., 2019. Anais... Lisboa, Instituto de Educação da Universidade de Lisboa, 2020. Disponível em: https://drive.google.com/file/d/1ydejwcPu_7fhVrQjV9Oljmp95SkrdkfO/view. Acesso em: 13 abr. 2021.

UNICAMP. Diretoria Acadêmica. Regimento Geral da Graduação, 2020. Disponível em: https://www.dac.unicamp.br/portal/graduacao/regimento-geral. Acesso em: 13 mar. 2020.

\section{Marcia Strazzacappa}

Professora Livre-Docente aposentada da Faculdade de Educação da Universidade Estadual de Campinas/SP. Atualmente é Professora Visitante Sênior do Prof-Artes da Universidade Federal da Paraíba. Graduada em Dança e em Pedagogia e Mestre em Educação pela Unicamp. Doutora em Artes pela Universidade de Paris. Membro do Laboratório de Estudos sobre Arte, Corpo e Educação (LABORARTE) da FE-Unicamp.

ORCID: https://orcid.org/0000-0002-4118-6572

E-mail: marciastrazzacappa@gmail.com

Currículo: http://lattes.cnpq.br/1574008360415424

Recebido em 23 de fevereiro de 2021 Aceito em 24 de abril de 2021 